\title{
Quod ore simul et opera docuit Hieronymus confessor, doctor maximus: Evhološka bese- dila na čast svetemu Hieronimu ter variabilnost njihovih prevodov
}

Nikolaj Aracki Rosenfeld OCist*

Evhološka besedila na čast svetemu Hieronimu segajo od prvih omemb v Gelazijevem zakramentarju ${ }^{1}$ preko gellonskega zakramentarja, ${ }^{2}$ fuldskega zakramentarja, ${ }^{3}$ lateranskega misala iz 12 . stoletja ${ }^{4}$ ter rimskega misala Pija v. ${ }^{5}$ do aktualnega rimskega misala Pavla vi. $^{6} \mathrm{~V}$ smislu Hieronimovega vodila "magis sensum e sensu quam ex verbo verbum transferens « $^{7}$ ter v luči inštrukcij za pravilno izvajanje

* Teološka fakulteta Univerze v Ljubljani, Poljanska cesta 4, Ljubljana, nikolaj. aracki@teof.uni-lj.si.

1 Liber sacramentorum Romanae Aecclesiae ordinis anni circuli (Cod. Vat. Reg. lat. 316/Paris Bibl. Nat. 7193, 41/56), Sacramentarium Gelasianum.

2 Liber Sacramentorum Gellonensis: Textus.

3 Prim. Sacramentarium Fuldense saeculi $x$. Cod. Theol. 231 der K. Universitätsbibliothek zu Göttingen: Text und Bilderkreis (43 Tafeln).

4 Vetus Missale Romanum Monasticum Lateranense, anno 1752 a Nicolao Antonellei editum.

5 Missale Romanum ex decreto ss. Concilii Tridentini restitutum Summorum Pontificium cura recognitum.

6 Prim. Missale Romanum ex decreto Sacrosancti Oecumenici Concilii Vaticani II instauratum auctoritate Pauli PP. VI promulgatum Ioannis Pauli PP. II cura recognitum.

7 Hieronimov uvod v Judito iz Vulgate navaja Movrin, »Hieronimov prevajalski credo«, 54 . 
konstitucije o svetem bogoslužju ${ }^{8}$ bi bilo potrebno pristopiti tudi $\mathrm{k}$ novi evhologiji na čast Hieronimu, ki jo prinaša misal Pavla vi. Ta je sestavljena tudi iz besedil koncilske konstitucije o svetem bogoslužju »Sacrosanctum Concilium $«{ }^{9}$

\section{EVHOLOŠKE ZBIRKE ALI ZAKRAMENTARJI}

Misal svetega Pavla vi. je sad liturgične prenove Drugega vatikanskega vesoljnega cerkvenega zbora in skupna ciljna točka stoletnega procesa liturgične vede v službi skupnosti verujočih. Od rimskega misala, ki ga je promulgiral papež Pij v. leta 1570 po naročilu tridentinskega cerkvenega zbora, ter preko počasnega oblikovanja liturgične teologije in spodbud, ki jih je tej vedi prineslo liturgično gibanje, je Drugi vatikanski cerkveni zbor pripeljal do konstitucije Sacrosanctum Concilium, na kateri temelji splošna prenova rimskega misala. V apostolski konstituciji, s katero je utemeljil prenovljeni Rimski misal, je papež Pavel vi. zapisal: »Podrobna pozornost je namenjena oracijam, ki niso le zgolj mnogo številčnejše, temveč bolje odgovarjajo novim potrebam sodobnega časa ${ }^{10}{ }^{10}$ Mnoge, posebej starejše, so popravljene v zvestobi najstarejšim virom.

Obogatitev oracionala v rimskem misalu, neuradno imenovanem tudi misal Pavla VI., predstavlja v primerjavi s prejšnjim rimskim misalom (tudi misalom Pija v.) ne le povečano število oracij, ${ }^{11}$ ki jih je vsaj dvakrat toliko, temveč v večjem in širšem prevzemanju evhološkega materiala iz najstarejših zakramentarjev. Ti predstavljajo dragoceno dediščino latinske cerkve in njene evhologije.

Zato prenovljeni misal jasneje izpostavlja dva temeljna dogodka zgodovine odrešenja - učlovečenje in Jezusovo rojstvo ter odrešenje in veliko noč. Čas med letom za razliko od adventnega in postnega časa, ki pripravljata, posebej ob nedeljah proslavlja celoto Kristusove skrivnosti. Sestavlja ga 34 formularjev. Misal je še

8 Prim. Kongregacija za bogoslužje in disciplino zakramentov: Inter oecumenici (26. 9. 1964), Tres abhinc annos (4. 5. 1967), Comme le Prévoit (25. 1. 1969), Liturgicae instaurationes (5. 9. 1970), Varietates legitimae (25. 1. 1994), Liturgiam authenticam (28. 3. 2001).

9 Concilium Oecumenicum Vaticanum II, »Konstitucija o svetem bogoslužju «, v: Koncilski odloki: konstitucije, odloki, izjave, poslanice 2. vatikanskega vesoljnega cerkvenega zbora (1962-1965), 62-93.

10 Rimski misal - kakor ga je naročil prenoviti II. Vatikanski cerkveni zbor in ga je razglasil papež Pavel vi., $12^{*}$.

11 Braga, »Il Proprium de Sanctis«, 405-440. 
posebej obogaten v svetih časih, kjer ima vsak dan svojo evhološko formulo. Za primerjavo - v obdobju adventnega in božičnega časa je v prenovljenem misalu 102 oracij v 47 formularjih. V prejšnjem je bilo 60 oracij, razdeljenih v zgolj 19 formularjev. Povečano število oracij gre $v$ glavnem na račun oracij iz obstoječih starih zakramentarjev (66). Le štiri so popolnoma nove, nekatere od prejšnjih so migrirale. Kriterij, ki je vodil migracijo ali zamenjavo, je sovpadanje v širšem načrtu, po katerem naj vsak od svetih časov jasneje odraža svojo temeljno značilnost. Zato denimo glavni mašni prošnji prvih dveh adventnih nedelj poudarjata drugi Kristusov prihod, medtem ko glavni mašni prošnji v drugi polovici adventa poudarjata in premišljujeta skrivnost novega rojstva Božjega sina.

Zakramentarji so liturgične knjige, ki vsebujejo molitve - in ne drugih elementov bogoslužja - ter so predpisane in pridržane za voditelja bogoslužja. Vsebujejo torej evhološke formularje za maše in druga liturgična dejanja (podeljevanja zakramentov, posvetitev cerkve, pogrebni obredi).

Od številnih zakramentarjev, ki jih danes poznamo predvsem iz obdobja 6. in 8. stoletja, so temeljni trije, na katere se nanašajo vsi ostali. To so Leonov, Gelazijev in Gregorijev zakramentar. Imenujejo se po papežih Leonu Velikem (440-461), Gelaziju I. (492-496) in Gregoriju Velikem (590-604). Zgodovina nastanka teh zakramentarjev je $\mathrm{z}$ njihovimi odnosi in njihovo vzajemno soodvisnostjo vse prej kot jasna zgodba, ki temelji predvsem na delovnih hipotezah včasih nasprotujočih si mnenj različnih raziskovalcev. ${ }^{12}$

Leonov ali veronski zakramentar, imenovan po kapiteljski knjižnici v Veroni, v bistvu sploh ni pravi zakramentar, ampak odseva obdobje, ko uradne liturgične knjige še niso obstajale. Je bolj za privatno uporabo narejena zbirka različnih serij maš, pogosto $\mathrm{z}$ več formularji za isto mašo. Te niso razvrščene po liturgičnem letu, ampak po civilnem.

Rokopis se začenja $\mathrm{z}$ mesecem aprilom in ga najprej sestavljajo libelli missarum, ki v obliki posamičnih in neodvisnih knjižic prinašajo mašni formular za določeno praznovanje - recimo za praznike cerkvenega leta, za godove svetnikov in mučencev ali za druge potrebe. Takšni libelli so se uporabljali in ohranili v titularnih cerkvah mesta Rima ali v njegovih bazilikah, še zlasti pa v papeškem arhivu svetega Janeza v Lateranu.

12 Jungmann, Missarum Sollemnia: Origini, liturgia, storia e teologia della Messa romana. 
Libelli Leonovega zakramentarja vodijo $\mathrm{v} 5$. in 6 . stoletje in odsevajo najbolj oddaljene izvire latinskih evholoških formularjev. Med avtorje lahko prištevamo nekatere papeže, Leona Velikega, Gelazija I. in Vergilija (538-555), medtem ko sodi zaključna redakcija zbirke $\mathrm{v}$ čas okrog druge polovice 6. stoletja.

Gelazijev zakramentar iz kodeksa Reginensis 316, shranjen v Vatikanski knjižnici, je v nasprotju z Leonovim pravi zakramentar. Evhološki material je organiziran v tri knjige, s temporalom, sanktoralom, nedeljami časa med letom in različnimi obrednimi ter votivnimi mašami.

Rokopis je bil urejen med Franki, izvira iz druge polovice 8. stoletja ter omogoča predstavo o liturgiji v Rimu med 7. in 8. stoletjem. Vsebuje 16 formularjev za nedeljske maše, ki jih je sestavil papež Gelazij (in torej sodijo v 6. stoletje), ter druge kompozicije prejšnjih in kasnejših papežev. Izvor Gelazijevega zakramentarja, ki vsebuje dva različna tipa formularjev (bodisi z dvema bodisi z eno mašno prošnjo) še ni povsem razjasnjen. Uveljavljena teza o njegovem nastanku, proti kateri sicer obstaja več nasprotnih argumentov, razloži sledi starih virov s predpostavko o rimski liturgični knjigi, ki so jo kasneje predelali z galikanskimi knjigami. ${ }^{13} \mathrm{~V}$ najmlajših delih Gelazijevega zakramentarja je mogoče prepoznati soodvisnost z Gregorijevim zakramentarjem. Toda ta soodvisnost je dvosmerna. Po tej tezi je Gelazijev zakramentar obstajal najprej v Rimu, namenjen uporabi v titularnih cerkvah.

Gregorijev zakramentar, za razliko od Leonovega in Gelazijevega ohranjen v številnih izvodih od 8. stoletja dalje, ima naslov, ki knjigo pripisuje Gregorju Velikemu.

Kritična izdaja Gregorijevega zakramentarja razlikuje dva tipa. Tip 1 je papeški zakramentar. Uporabljal ga je papež v svoji baziliki svetega Janeza v Lateranu ter pri stacionalnih mašah v drugih rimskih bazilikah na določene dneve v letu. Verjetno je nastal v času pontifikata papeža Honorija I. (625-638) in se počasi bogatil z novimi prazniki do svoje dopolnitve pod Gregorijem II. (715-731). En izvod tega Gregorijevega zakramentarja - tip 1 je papež Hadrijan I. (772-795) poslal Karlu Velikemu, ko je ta želel poenotiti sensum Romanum s frankovsko liturgijo. To je takoimenovani Hadrianum, ki ga hrani kodeks v Cambraiu (Ms 164). 
V drugi polovici 7. stoletja je bil ta Gregorijev zakramentar - tip 1 na osnovi različnih virov (predvsem Gelazijevega zakramentarja) predelan za neko prezbitersko cerkev. Nastal je Gregorijev zakramentar - tip 2, ki je prezbiterialen. Ohranjen je v kodeksu D47 v Padovi.

Med letoma 760 in 770 sta se združila Gregorijev zakramentar - tip 2 in Gelazijev zakramentar. Nastal je nov zakramentar, ki vsebuje skoraj vse njune oracije, vendar $\mathrm{z}$ dodatkom iz nekaterih starih galikanskih virov. Znan je kot Gelasianum 8. stoletja ali kot frankovski Gelasianum. V svoji najstarejši redakciji se je ohranil kot zakramentar iz Gellona, a je v svoji sestavi nepravilen zaradi ponavljanja podobnih besedil, ponekod tudi različnih besedil za isti formular. Zato je sledila revizija, iz katere je nastal drugi frankovski Gelasianum. Iz te revizije izhajajo mnogi pomembni rokopisi, med njimi zakramentar iz Angoulemea in zakramentar iz St. Gallena.

Gregorianum - tip 1, ki ga je proti koncu 8. stoletja Hadrijan I. poslal Karlu Velikemu, je bil za liturgično rabo v marsičem nepopoln. Ob njem so uporabljali še zgoraj omenjeni frankovski Gelasianum, ki pa je bil preveč obširen. Zato je v zadnjem desetletju 8. stoletja nastal tako imenovani supplementum, sestavljen iz oracij frankovskega Gelazijevega zakramentarja. S tem dodatkom se zaključi »trilogija « Gregorijevega zakramentarja, ki ga tako sestavljajo: Adrianum ex authentico (Gregorianum - tip 1 ali papeški), supplementum (Anianense) in Gregorianum Pauense (tip 2 ali prezbiterialni).

$\mathrm{Ob}$ naštetih virih je sodobni rimski misal prevzel tudi oracije drugih latinskih liturgičnih družin; iz ambrozijanske liturgije preko zakramentarja iz Bergama (Bergomense), iz galikanske liturgije preko gotskega misala (missale Gothicum), iz mozarabske liturgije preko vizigotskega oracionala ali iz Mozarabske knjige zakramentov (Liber mosarabicus sacramentorum).

\section{OBLIKA RIMSKEGA FORMULARJA}

Za rimski obred predstavljajo oracije hrbtenico liturgije, definirajo ga $\mathrm{z}$ lastnim karakterjem (sobrietas Romana). Ta lastnost latinske rimske liturgije je sestavljena iz mnoštva in različnosti oracij. ${ }^{14}$ Rimski mašni formular praviloma sestavljajo ena glavna prošnja (collecta), prošnja nad darovi (super oblata) in prošnja po obhajilu (post communionem), praznični formular pa je lahko razširjen še $\mathrm{z}$ hvalospevom (praefatio), $\mathrm{z}$ variabilnimi deli kanona in $\mathrm{z}$ molitvi- 
jo nad ljudstvom (super populum). Spremljajo ga še spevi (antifona ad introitus in antifona ad communionem), ki so iz Svetega pisma povzeti dobesedno ali v parafrazi. Variabilne formule so odvisne od liturgičnega časa ali določenih priložnosti. ${ }^{15}$

Oracije prenovljenega misala iz omenjenih zakramentarjev niso zgolj prepisane, ampak so pogosto tudi spremenjene. Zamenjana je lahko ena beseda ali celotna fraza, združena sta lahko dva različna elementa ali pa je dodan nov člen.

Poleg sprememb pri besedilih je evolucijo doživel tudi rimski koledar. Njegove prve korenine so v Filokalovem kronografu in $\mathrm{v}$ tako imenovanem Hieronimovem martirologiju. Prve očitne liturgične sledi pa so $\mathrm{v}$ zgoraj opisanih zakramentarjih. Obogaten z galikanskim izročilom se je $\mathrm{v}$ karolinški dobi ta koledar razširil po vsej Evropi. V ta razvoj je nato posegel Tridentinski cerkveni zbor in njegovo evolucijo je pričela nadzorovati kongregacija za svete obrede oziroma bogoslužje in disciplino zakramentov.

\section{EVHOLOŠKA BESEDILA V ČAST SVETEMU HIERONIMU}

\section{Sacramentarium Gelasianum}

1246 Communicantes, et memoriam venerantes, in primis gloriosae semper Virginis Mariae, Genetricis Dei et Domini nostri Iesu Christi: sed et beatorum Apostolorum ac Martyrum tuorum, Petri et Pauli, Andreae, Iacobi, Ioannis, Thomae, Iacobi, Philippi, Bartholomaei, Matthaei, Simonis et Thaddaei: Lini, Cleti, Clementis, Xysti, Cornelii, Cypriani, Laurentii, Chrysogoni, Ionnis et Pauli, Cosmae et Damiani, <Hilari, Martini, Augustini, Gregorii, Hieronymi Benedicti $>^{16}$ et omnium Sanctorum tuorum; quorum meritis precibusque concedas, ut in omnibus protectionis tuae muniamur auxilio. (Per Christum Dominum nostrum). Amen. ${ }^{17}$

$1246 \mathrm{~V}$ občestvu združeni obhajamo spomin najprej častitljive vedno Device Marije, matere Boga in našega Gospoda Jezusa Kristusa: pa tudi tvojih svetih apostolov in mučencev, Petra in Pavla, Andreja, Jakoba, Janeza, Tomaža, Jakoba, Filipa, Jerneja, Mateja, Simona in Tadeja, Lina, Kleta, Klementa, Siksta, Kornelija, Cipri-

16 Ta imena so v rokopisu izbrisana, a še vedno berljiva.

17 Liber sacramentorum Romanae Aecclesiae ordinis anni circuli (Cod. Vat. Reg. lat. 316/Paris Bibl. Nat. 7193, 41/56). 
jana, Lavrencija, Krizogona, Janeza in Pavla, Kozma in Damijana, $<$ Hilarija, Martina, Avguština, Gregorja, Hieronima, Benedikta $>$ in vseh tvojih svetnikov; po njih zasluženju in priprošnjah, nam podeli, da bomo v vsem deležni tvojega varstva. (Po Kristusu našem Gospodu). Amen

\section{Misal iz Bobbia}

Communicantes, et memoriam venerantes, in primis gloriosae semper Virginis Mariae, Genetricis Dei et Domini nostri Iesu Christi: sed et beatorum Apostolorum ac Martyrum tuorum, Petri et Pauli, Andreae, Iacobi, Ioannis, Thomae, Iacobi, Philippi, Bartholomaei, Matthaei, Simonis et Thaddaei: Lini, Cleti, Clementis, Xysti, Cornelii, Cypriani, Laurentii, Chrysogoni, Ionnis et Pauli, Cosmae et Damiani, Hilari, Martini, Augustini, Gregorii, Hieronymi Benedicti et omnium Sanctorum tuorum; quorum meritis precibusque concedas, ut in omnibus protectionis tuae muniamur auxilio. ${ }^{18}$

V občestvu združeni obhajamo spomin najprej častitljive vedno Device Marije, matere Boga in našega Gospoda Jezusa Kristusa: pa tudi tvojih svetih apostolov in mučencev, Petra in Pavla, Andreja, Jakoba, Janeza, Tomaža, Jakoba, Filipa, Jerneja, Mateja, Simona in Tadeja, Lina, Kleta, Klementa, Siksta, Kornelija, Ciprijana, Lavrencija, Krizogona, Janeza in Pavla, Kozma in Damijana, Hilarija, Martina, Avguština, Gregorja, Hieronima, Benedikta in vseh tvojih svetnikov; po njih zasluženju in priprošnjah, nam podeli, da bomo v vsem deležni tvojega varstva.

\section{Sacramentarium Gellonensis}

Sancti nos quesumus domine hyronimi natalicia votiva laetificent, et ad sue beneficiis intercessionis adtollant. Per $[\ldots]^{19}$

Gospod, prosimo naj nas razveseljuje zaobljubljen rojstni dan za nebesa svetega Hieronima in naj nam po njegovi priprošnji prinaša milostne dobrote. Po [...] 


\section{Sacramentarium Fuldense}

(collecta) Deus qui nos annua beati Hieronimi confessoris tui festivitate latificas, da nobis eius intervenientibus meritis et perpetua protectione muniri et salutari gaudere profectu. Per [...]

Alia (collecta) Deus qui nobis per beatum Hieronimum confessorem sacerdotemque tuum scripture sanctae veritatem et mystica sacramenta revelare dignatus es, presta quesumus, ut cuius natalicia colimus, eius semper et erudiamur doctrinis et meritis adiuuemur. Per $[\ldots]^{20}$

(glavna prošnja) O Bog, ki nas vsako leto razveseljuješ s praznikom svetega spoznavalca Hieronima, po priprošnji njegovih zaslug nam daj, da bomo utrjeni s trajno zaščito in se veselili napredka v zveličanju. Po $[\ldots]$

Druga (glavna prošnja) O Bog, ki si nam po svojem spoznavalcu in duhovniku svetem Hieronimu blagovolil razodeti resnico Svetega pisma in skrivnosti zakramentov, prosimo podeli, ko obhajamo njegovo rojstvo za nebesa, da nas bodo vedno poučevali njegovi nauki in nam bodo $\mathrm{v}$ pomoč njegove zasluge. Po [...]

\section{Vetus missale Romanum monasticum Lateranense}

(collecta) Ominpotens sempiterne deus, qui aecclesiae tue beatum Hieronimum confessorem scripturae sanctae et verum interpretem et tractatorem catholicum tribuisti, concede propitius, ut eius semper erudita doctrina stabili fide in veneratione tui nominis et agnitione proficiat. Per $[\ldots]^{21}$

(glavna prošnja) Vsemogočni večni Bog, ki si svetega spoznavalca Hieronima priskrbel svoji Cerkvi za resničnega razlagalca in pravovernega razpravljavca svetega Pisma, milostno nakloni, da nam bo njegov izvéden nauk o trdni veri vedno koristil za čaščenje in priznavanje tvojega imena. Po [...]

Sacramentarium Fuldense saeculi x. Cod. Theol. 231 der K. Universitätsbibliothek zu Göttingen: Text und Bilderkreis (43 Tafeln).

21 Vetus missale Romanum monasticum Lateranense, anno 1752 a Nicolao Antonellei editum. 


\section{Missale secundum consuetudinem curiae Romanae}

(collecta) Deus, qui populo tuo aeternae salutis beatum ... ministerium tribuisti, praesta, quaesumus, ut quem doctorem habuimus in terris, intercessorem quoque semper habere mereamur in caelis. Per $[\ldots]^{22}$

(glavna prošnja) O Bog, ki si svojemu ljudstvu dal blaženega ... za služabnika večnega zveličanja, daj, prosimo, da bomo njega, ki smo ga za učitelja imeli na zemlji, vedno vredni imeti tudi za priprošnjika v nebesih. Po [...]

\section{Missale Romanum ex decreto ss. concilii Tridentini}

(collecta) Deus, qui Ecclesiae tuae in exponendis sacris Scripturis beatum Hieronymum Confessorem tuum, Doctorem maximum providere dignatus es: praesta, quaesumus; ut, ejus suffragantibus meritis, quod ore simul et opere docuit, te adjuvante exercere valeamus. Per Dominum nostrum. ${ }^{23}$

(glavna prošnja) O Bog, ki si v svojem svetem spoznavalcu Hieronimu blagovolil priskrbeti svoji Cerkvi velikega učitelja v razlaganju svetega Pisma, podeli, prosimo, da bomo po njegovih zaslugah mogli izvrševati, kar je učil z besedo in z dejanjem. Po našem Gospodu.

\section{Missale Romanum ex decreto ss. oecumenici concilii Vaticani II}

(collecta) Deus, qui beato Hieronymo presbytero suavem et vivum Scripturae Sacrae affectum ${ }^{24}$ tribuisti, da, ut populus tuus verbo tuo uberius alatur, et in eo fontem vitae ${ }^{25}$ inveniat. Per Dominum nostrum.

22 Missale secundum consuetudinem curiae romanae, Ms. Ottob. lat. 356, še neobjavljeni kodeks hrani Bibliotheca Apostolica Vaticana.

23 Missale Romanum ex decreto ss. concilii Tridentini restitutum summorum pontificium cura recognitum.

24 Prim. Konstitucija o svetem bogoslužju, Sacrosanctum concilium 24: "oportet ut promoveatur ille suavis et vivus sacrae Scripturae affectus, quem testatur venerabilis rituum«.

25 Prim. Vulgata: »apud te fons vitae, in lumine tuo videbimus lumen« (Ps 15,10), »lex sapientis fons vitae ut declinet a ruina mortis (Prov 13,14), "fons vitae eruditio possidentis doctrina stultorum fatuitas« (Prov 16,22). 
(super oblata) Tribue, nobis, Domine, ut, exemplo beati Hieronymi, verbum tuum meditati, ad salutarem hostiam maiestati tuae offerendam promptius accedamus. Per Christum.

(post communionem) Sancta tua quae sumpsimus, Domine, de beati Hieronymi celebritate laetantes, tuorum excitent corda fidelium, ut, sacris intenta doctrinis, intellegant quod sequantur, et sequendo vitam obtineant sempiternam. Per Christum. ${ }^{26}$

(glavna prošnja) O Bog, svetemu duhovniku Hieronimu si podelil veselje in ljubezen do Svetega pisma; daj, da se bo tvoje ljudstvo obilneje hranilo s tvojo besedo in v njej našlo vir življenja. Po našem Gospodu.

(prošnja nad darovi) O Bog, po zgledu svetega Hieronima smo premišljevali tvojo besedo; nakloni nam, da bomo tako bolj pripravljeni darovali tvojemu veličastvu zveličavno žrtev. Po Kristusu.

(prošnja po obhajilu) Tvoji sveti darovi, ki smo jih prejeli, Gospod, ko se veselimo slovesnosti svetega Hieronima, naj spodbudijo srca tvojih vernih, da bodo, pozorna do svetih naukov, razumevala čemu naj sledijo, in s sledenjem dosegla večno življenje. Po Kristusu.

\section{PREVAJANJE LITURGIČNIH BESEDIL}

Filološka prevajalska metoda predpostavlja, da ima besedilo kot svojo temeljno karakteristiko homogenost jezika. Z drugimi besedami, določeno liturgično formulacijo prevaja s predpostavko, da je formula od začetka do konca napisana v istem tipu latinskega jezika (torej sestavljena od enega avtorja v točno določenem trenutku kulturnega in jezikovnega razvoja). ${ }^{27}$ Če je ta kriterij še lahko veljaven za mnoga (čeprav nikakor ne za vsa) antična besedila, pa ni več veljaven za liturgična besedila, ki so izšla po prenovi drugega vatikanskega cerkvenega zbora. Natančneje, ko je nastal Gelazijev zakramentar, je urednik delal na podlagi predhodnih evholoških besedil, ki jih je našel v Leonovem zakramentarju in v katerih so zajeti rimski libelli, a je uporabil tudi novejša, nedavno nastala besedila, tem pa dodal še svoja. Liturgično občestvo v

Missale Romanum ex decreto sacrosancti oecumenici concilii Vaticani II instauratum auctoritate Pauli PP. VI promulgatum Ioannis Pauli PP. II cura recognitum. 
Rimu, ki mu je bil ta zakramentar namenjen, ni imelo težav s sprejemanjem liturgičnih besedil iz Gelazijevega zakramentarja, tako starih kot novejših. Urednik ${ }^{28}$ (oziroma z drugačno terminologijo pošiljatelj) in občestvo (oziroma prejemnik) sta imela namreč veliko skupnih elementov: enako vero, enake zgodovinske okoliščine, pa tudi bolj ali manj enak jezik, enako kulturo, enake teološke in kulturne predstave, enako razumevanje gest, prostorov, odnosov med ljudmi ... Urednik kot pošiljatelj in občestvo kot prejemnik sta živela znotraj enakega kulturnega sistema $\mathrm{z}$ enakimi izrazi in enakim jezikom, ki je izražal njuno vero in njeno obhajanje oziroma praznovanje. V obdobju pred nastankom Gelazijevega zakramentarja je bilo enako. Enak pojav srečamo tudi v predhodnem obdobju; izjema je seveda jezik, saj je v četrtem stoletju rimska liturgija prešla z grškega jezika na latinskega. Praviloma je bil urednik tudi subjekt občestvenega obhajanja ali je bil občestvu zelo blizu.

Položaj pa v luči zgodovinskega razvoja postaja kompleksnejši. Dokler besedila nastajajo in izražajo vero določene kulture, so zlahka uporabna za liturgično občestvo, ki je njihov prejemnik. Od trenutka, ko se različna kulturna področja diferencirajo, pa je mogoče opaziti poseben pojav: liturgična besedila težijo k bolj kristaliziranim in poenotenim izrazom, prične se ločitev med liturgičnim besedilom in liturgičnim dejanjem ali gesto. S Tridentinskim cerkvenim zborom so posledice že očitne, govoriti je mogoče o kulturi liturgične knjige (jezik je v besedilu, geste pa v rubrikah). Njen kulturni kontekst je korenito drugačen od jezika in kulturnega konteksta občestva, ki pa obhaja in praznuje prav s temi liturgičnimi knjigami.

Danes je položaj spet drugačen kot v dobi Tridentinskega koncila. Če je takratni kulturni kontekst, ki ga predpostavlja liturgično besedilo, še ohranjal relativno bližino s kulturnim kontekstom občestva, so se v sodobnem času škarje med liturgičnim besedilom in občestvom še bolj razprle. Ne samo zaradi jezika, temveč zaradi splošnega okvira kulture. Tridentinsko obdobje zaznamuje predznanstvena kultura, tako v teološkem kot v profanem območju. Galileo Galilei je morda simbolni predstavnik, ki ponazarja prehod v znanstveno kulturo; toda liturgično besedilo še vedno izraža predgalilejsko kulturo.

Današnje liturgično besedilo je namreč skupek formul in formulacij evholoških besedil, ki imajo raznolik izvor. Rimski misal Pavla vi. je sestavljen iz vrste evholoških besedil, ki so prepros- 
to prepis nekaterih častitljivih in starodavnih zakramentarjev; druga so sestavljena iz fragmentov liturgičnih besedil različnih obdobij; spet druga so sestavljena iz delčkov antičnih in delčkov modernih besedil, še druga iz antičnih besedil in novih kompozicij, in slednjič so tu besedila, ki so popolnoma nova. ${ }^{29}$

$\mathrm{V}$ tem položaju je končni urednik, naš sodobnik, ki je uporabil antična besedila, podedoval formule prejšnjih urednikov. Pri tem je nedvomno delil isto vero s predhodnimi uredniki. Toda njegov zgodovinski kontekst je bistveno spremenjen, še bolj pa so se spremenile kulturne in celo teološke sheme. Današnji uporabnik nima več značilnosti uporabnikov iz preteklosti. Tudi odnos med urednikom in uporabnikom še zdaleč ni enak tistemu med papežem Gregorjem Velikim in njegovim občestvom. Besedilo, umeščeno $\mathrm{v}$ tak odnos, zagotovo spremeni svojo fizionomijo. Reči je mogoče, da je danes besedilo tujec v odnosu do današnjega občestva. Sestavljeno je v jeziku, ki se v medsebojni komunikaciji ne uporablja več. V sebi nosi teološke in kulturne sestavine dolgih in zelo različnih obdobij. Namenjeno je uporabniku, občestvu, ki ima vrsto drugačnih kulturnih predpostavk kot besedilo samo. Editio typica rimskega misala je namenjena za vesoljno Cerkev. Drugače povedano, misal je za katoličana zahodne kulture, pa tudi za katoličane bližnjevzhodne kulture, pa afriške, latinskoameriške, japonske, kitajske, polinezijske ... To pomeni sprejetje liturgičnega besedila v nemalo različnih kulturnih variantah.

Te ugotovitve kažejo, da je zgolj filološka metoda redko zadostna in zadovoljiva za množico modernih jezikov. To dejstvo odpira nove prevajalske poti. ${ }^{30}$ Problem liturgičnega konteksta postaja ključen za razumevanje besedila. Besedilo, ki je sicer temeljni element študija liturgike, je treba najprej prebrati kot tako, $\mathrm{z}$ upoštevanjem literarnega vidika, ${ }^{31}$ nato pa še znotraj celebrativne dinamike, ki jo določajo norme in praksa.

Umestitev besedila znotraj celebrativnega konteksta pomeni prepoznati besedilo v odnosu do obreda, gest, obhajane skrivnosti in liturgičnega časa. Poenostavljeno to pomeni umestiti besedilo znotraj obrednega programa v vsej polnosti. ${ }^{32}$ Besedilo

Dumas, »Le Orazioni del Messale: Criteri di scelta e composizione«, 92-102.

Nakagaki, "Metodo integrale: Discorso sulla metodologia nell' interpretazione dei testi eucologici«, 269-286.

Sodi, »La latinitas dei libri liturgici: L'eucologia del Tempus Adventus nel Missale Romanum di Paolo vi«, 375-488.

Pecklers, Dynamic Equivalence: The Living Language of Christian Worship. 
je le del širšega besedila, ki ga sestavljajo majhna evhologija, druga evhološka besedila, biblična besedila, ki so del prilegajočega formularja, velika evhologija in biblična besedila iz lekcionarja. K besedilni celoti formularja vsekakor sodijo še besedila znotraj molitvenega bogoslužja. K besedilu pa lahko prištejemo še gestualne in druge neverbalne kodekse, katerih pomen pogosto razodeva prav besedilo samo. Končni horizont je še tako imenovani celebrativni kontekst obhajane verske skrivnosti, umeščen v določen liturgični čas.

Tako široko razumljeno besedilo preneha biti pisano besedilo; razumemo ga kot dejanje, kot jezikovni dogodek. ${ }^{33}$ Evhološka besedila, ki so sicer nastala, da bi bila izgovorjena, postajajo učinkoviti dogodki v veri, kjer reči pomeni storiti. V pripravi prevoda iz evhološkega izročila je zato dobro razločevati med antično evhologijo in evhologijo, ki jo vsebujejo sodobne liturgične knjige.

\section{NAVODILA SVETEGA SEDEŽA \\ O PREVAJANJU LITURGIČNIH BESEDIL}

Pokoncilski dokumenti katoliške Cerkve določajo smernice za prevajanje liturgičnih besedil. Tu so najprej navodila, ki jih je Sveti sedež pripravil za izvajanje konstitucije o bogoslužju. Prva tri so sledila v začetku pokoncilskega obdobja (1964-1970). Zadnji dve sodita v kasnejše obdobje.

\section{Inter oecumenici (26. september 1964)}

Gre za prvi aplikativni vodnik po omenjeni konstituciji, ki zadeva vse njene člene ter ponudi prvo konkretno udejanjenje - tako splošnih kriterijev za uvajanje prenove kakor tudi posamičnih izbir v zvezi z zakramenti, evharistijo, zakramentali, molitvenim bogoslužjem in arhitekturo. ${ }^{34}$ Zanimivo je, da sta pod dokumentom podpisana tako kongregacija za obredje kot tudi posebni svet (consilium) za izvajanje konstitucije, ustanovljen istega leta. 
Tres abhinc annos (4. maj 1967) (skupaj z Musicam sacram in Eucharisticum mysterium)

Leta 1967 izide drugo navodilo za izvajanje konstitucije, ${ }^{35}$ skupaj $\mathrm{z}$ dokumentom o glasbi ${ }^{36}$ in evharistiji. ${ }^{37}$ Besedilo o glasbi je pravzaprav dopolnitev prvega navodila, ki se z njo ni ukvarjalo. Dokument je odgovor na mnoge težave in nasprotovanja, ki jih je že povzročala prenova.

\section{Liturgicae instaurationes (5. september 1970)}

Tretje navodilo je dokument preloma. ${ }^{38}$ Svet je bil tega leta združen $s$ kongregacijo, ki so jo sedaj preimenovali v Kongregacijo za bogoslužje. $Z$ ene strani dokument omejuje velika nasprotja, ki jih je povzročila prenova (tistih, ki bi spreminjali vse, in tistih, ki ne želijo ničesar spremeniti); $z$ druge strani pa spregovori o konkretnih vprašanjih (edinost med bogoslužjem božje besede in evharističnim bogoslužjem, pomen duhovniške molitve, prevajanje besedil). V šestih letih od prvega do tretjega navodila so postajale vedno bolj očitne napetosti in težave v konkretni recepciji velikega načrta, ki ga je imela koncilska konstitucija.

\section{Varietates legitimae (25. januar 1994)}

Čas, ki je pretekel do novega navodila, ${ }^{39}$ je pomenil obdobje cele generacije. Posledično to navodilo odgovarja na nove okoliščine, ki jih je globoko zaznamoval pontifikat Janeza Pavla II., zlasti njegov romarski značaj. Ta ga je tesno povezal $\mathrm{z}$ veliko različnostjo izročil in kultur znotraj Cerkve in po vsem svetu. Proces aktualizacije je terjal odgovor na občutliivost vernikov na različnih kontinentih; ob tem pa avtentičnost rimskega obreda ni smela obču-

35 Kongregacija svetih obredov, "Drugo navodilo za pravilno izvajanje Konstitucije o svetem bogoslužju«, 14-15; prim. Acta Apostolicae sedis 59 (1967): 442-448.

36 Kongregacija svetih obredov, "Navodilo o glasbi pri svetem bogoslužju«, 307.

37 Kongregacija svetih obredov, "Navodilo o češčenju evharistične skrivnosti", 55-80; prim. Acta Apostolicae sedis 59 (1967): 539-573.

38 Kongregacija za bogoslužje, »Tretje navodilo za pravilno izvajanje Konstitucije o svetem bogoslužju«, 34-47; prim. Acta Apostolicae sedis 62 (1970): 692-704.

39 Kongregacija za bogoslužje in disciplino zakramentov, "Navodilo Varietates legitimae«, 295-297. 
titi osiromašenja. V tem navodilu so nekateri restriktivni kriteriji, ki želijo konzervirati »avtentičnost « rimskega obreda. Podobna obrambna in apologetična drža je zaznamovala tudi naslednje, zadnje navodilo.

\section{Liturgiam authenticam (28. marec 2001)}

To besedilo v središče postavi prav avtentičnost liturgije $\mathrm{e}^{40}-\mathrm{s}$ tem pa misli skoraj izključno zvestobo dobesednim prevodom latinščine v narodne jezike. Želi namreč preprečiti škodljivo izgubo tradicionalnega besedišča. Kar bi lahko storili interpretativni in dinamični prevodi, je sedaj zaupano predvsem homiliji in katehezi. Navodilo odraža veliko skrb ob nastajajoči krizi zdaj že druge pokoncilske generacije. Toda vprašanje ni zgolj prevajalsko, temveč postaja interpretativno, ko gre za pomen pastoralnega značaja koncila. Med prevajalci je povzročilo vrsto rezerviranih in tudi odklonilnih odzivov.

\section{Motu proprio Magnum principium (1. oktober 2017)}

Pomemben preobrat pomeni motuproprij papeža Frančiška Magnum principium, ki je stopil v veljavo 1. oktobra $2017 .{ }^{41}$ Gre za razmeroma kratko besedilo s spremembo zakonika Cerkvenega prava, ki pa prav s tem v globini omogoči tudi spremembo ustaljene institucionalne prakse. Navodilo Liturgiam authenticam je tako rekoč zacementiralo dobesedne prevode, da bi zagotovilo zvestobo latinskemu besedilu. Škofovska konferenca lahko v skladu z navodilom ustvari težje razumljiva besedila, potrebna stalne razlage; lahko pa jih prevaja veliko bolj svobodno, vendar takih prevodov kongregacija ne more potrditi. Sprememba 838. kanona Zakonika cerkvenega prava pa omogoča in uveljavlja načelo, da je pravzaprav nacionalni episkopat jamstvo zvestega prevoda; to ni več izključno Kongregacija za bogoslužje, katere pristojnost je sedaj bolj omejena. 
Niso vsi prevodi enaki in enakovredni, prav tako ni mogoče vedno prevajati $z$ istimi kriteriji; potrebna je elastičnost, ki jo navodilo $L i-$ turgiam authenticam omejuje. Ideal zvajanja prevajalskih kriterijev na zgolj dobesednost je povzročil paralizo besedil. Po skoraj dvajsetih letih petega navodila zorijo med liturgičnimi prevajalci novi predlogi ${ }^{42}$ med katerimi je potrebno omeniti tri prevajalske modalitete:

1. zvesti prevod, kadar živi jezik izvirnika ne posnema zgolj v pomenu posamičnih besed, ampak tudi na oblikovni in stilistični ravni;

2. korektivni prevod, kadar novo besedilo popravi manjkajoče vsebine izvirnika; primer je denimo srednjeveški koncept placatio, ki ga je sodobna soteriologija že presegla;

3. dopolnjujoči prevod, ko nova formulacija obogati in dopolni pomen izvirnika.

Podobni predlogi dokazujejo, da prevajanje ni zgolj preprost prenos izvirnega besedila, $\mathrm{v}$ katerem je polnost pomena in resnice, medtem ko so prevodi zgolj slabe in nezveste kopije. Prevod, opravljen s potrebnimi kompetencami, lahko izhodiščno besedilo obogati in ga oblikuje, da izrazi molitev, ki zmore postati lastna liturgičnim občestvom določene kulture in časa.

Apostolska konstitucija papeža Pavla vi. Missale Romanum z dne 3. aprila 1969, s katero je bil promulgiran novi misal, zatrjuje, da so oracije pripravljene s posebno skrbnostjo. Pri tem ne gre zgolj za povečano število, temveč želijo ustrezati novim potrebam časov, "ut novis horum temporum necessitatibus novae responderent ${ }^{4}{ }^{43}$ A vendar je po natančnejšem pregledu očitno, da le redke upoštevajo novo kulturo in dejanske potrebe časa ter izražajo spremenjeno in povečano zainteresiranost za potrebe planetarne skupnosti. (Značilen primer so slovesne molitve velikega petka, denimo deveta oracija za državne voditelje.)

Cerkev danes poudarja vlogo, ki jo imajo pristojne nacionalne škofovske konference, da zagotavljajo modernim jezikom in prevodom značaj, ki jim je lasten. Istočasno pa so dolžne vernikom zvesto posredovati pomen originalnega besedila in ob variabilnih kulturnih adaptacijah negovati edinost znotraj rimskega obreda. ${ }^{44} \mathrm{Nje}-$ gove avtentičnosti seveda ne pogojujejo izključno filološki kriteriji.

Prim. De Zan, „Dal Magnum principium alla necessità di una vi Istruzione?» 67-79; Grillo, Beyond Pius V.

43 Glej opombo 11.

44 Prim. papež Frančišek, apostolsko pismo Magnum principium. 
Dediščina tradicionalne evhologije je sad stoletnih predelav in nenehnega filtriranja. Je delo različnih avtorjev, pogosto velikih svetnikov, navdihnjenih s skupno vero celih narodov in kultur, ki so jo oblikovali svetopisemski in patristični viri. Je pogosto tudi delo dobe, ko je celotno božje ljudstvo intenzivno in aktivno oblikovalo bogoslužje kot nadaljevanje Kristusove skrivnosti - in torej zadnji trenutek zgodovine odrešenja. Zato Konstitucija o svetem bogoslužju poudarja, da Cerkev oznanja velikonočno skrivnost in jo obhaja in praznuje v vseh, ki so s Kristusom trpeli, umrli in z njim vstali v poveličano bivanje. Velikonočna skrivnost predstavlja ključni in temeljni kriterij teološkega, literarnega in pastoralnega vrednotenja evhologije. Zato mora prevod slediti teologiji. Šele ko je besedilo razumljeno, je lahko prevedeno. Zato je prevod delikatna operacija, ki se ne sme ustaviti pri zamenjavi enega označevalca $z$ drugim, ampak šele pri enakem pomenu. Prevod ni zamenjava etikete na istem predmetu; razumljivo je, da prevod ne more biti zgolj kalk iz izvornega jezika. Pred istim izzivom je stal sveti Hieronim.

Pri prevajanju liturgičnega besedila je opazna še danes preferenčna izbira filološke metode. ${ }^{45}$ Liturgično evhološko besedilo kot obredno znamenje in dogodek je sredstvo za sporazumevanje. Vendar je za vernike, ki praznujejo svete obrede, beseda tudi skrivnost, ki se je razodela v Kristusu. Zato je cilj prevoda liturgičnih besedil in svetopisemskih besedil za bogoslužje vernikom sporočati rešilno besedo o veri, jim omogočati, da izrazijo molitev vse Cerkve Gospodu. Zvestobe prevodov v moderne jezike zato ni mogoče presojati po posameznih besedah, ampak jo je treba iskati v kontekstu celotnega komunikacijskega dejanja, v skladu z lastnimi literarnimi zvrstmi in ob pozornem upoštevanju načinov za izražanje celotne katoliške vere.

\section{BIBLIOGRAFIJA}

Augé, Mathias. »Eucologia«. V: Liturgia, ur. Domenico Sartore, Achille Maria Triacca in Carlo Cibien, 761-771. Cinisello Balsamo: San Paolo, 2001.

___. »Principi di interpretazione dei testi liturgici«. V: La liturgia, momento nella storia della salvezza, ur. Burkhard Neunheuser, S. Marsili, M. Augé in R. Civil (Anamnesis 1), 159-179. Casale Monferatto: Marietti, 1979.

Braga, Carlo. »Il Proprium de Sanctis«. Ephemerides liturgicae 84 (1970): 405-440. 
Concilium oecumenicum Vaticanum II. »Konstitucija o svetem bogoslužju«. V: Koncilski odloki: konstitucije, odloki, izjave, poslanice 2. vatikanskega vesoljnega cerkvenega zbora (1962-1965), 62-93. Ljubljana: Nadškofijski ordinariat, 1980.

De Zan, Renato. "Dal Magnum principium alla necessità di una vi Istruzione?« Rivista liturgica 2 (2019): 67-79.

—. Note e appunti per una introduzione all'ermeneutica dei testi liturgici. Dispense "ad usum auditorum privatum" pro manuscripto, anno accademico 2009-2010. Rim: PIL, 2010.

Dumas, Alexandre, ur. Liber sacramentorum Gellonensis: Textus. CCL 159. Turnhout: Brepols, 1981.

___ . „Le Orazioni del Messale: Criteri di scelta e composizione«. Rivista liturgica 58 (1971): 92-102.

Foster, Reginald Thomas in D. P. McCarthy. »Collectarum latinitas«. V: Appreciating the Collect: An Irenic Methodology, ur. J.G. Leachman in D.P. McCarthy, Liturgiam Aestimare: Appreciating the Liturgy 1, 27-56. Farnborough: St Michael's Abbey Press, 2008.

Greimas, Algirdas Julien. Semantica strutturale: Ricerca del metodo. Rim: Meltemi, 2000.

Grillo, Andrea. Beyond Pius V: Conflicting Interpretations of the Liturgical Reform. Minnesota: Liturgical Press, 2013.

Jungmann, Josef A. Missarum Sollemnia: Origini, liturgia, storia e teologia della Messa romana. Torino: Marietti, 1961.

Kongregacija svetih obredov. »Drugo navodilo za pravilno izvajanje Konstitucije o svetem bogoslužju«. V: Prenovljeno bogoslužje, 14-15. Ljubljana: Slovenski medškofijski liturgični svet, 1981. Prim. Acta Apostolicae sedis 59 (1967): 442-448.

___ . "Navodilo o češčenju evharistične skrivnosti«. V: Prenovljeno bogoslužje, 55-8o. Ljubljana: Slovenski medškofijski liturgični svet, 1981. Prim. Acta Apostolicae sedis 59 (1967): 539-573.

___. „Navodilo o glasbi pri svetem bogoslužju«. V: Odloki o cerkveni glasbi: Ob stoletnici Pijevega motu proprija, 307 (Ljubljana: Družina, 2003).

___ . .Prvo navodilo za pravilno izvajanje Konstitucije o svetem bogoslužju«. V: Prenovljeno bogoslužje, 8-14. Ljubljana: Slovenski medškofijski liturgični svet, 1981. Prim. Acta Apostolicae sedis 56 (1964): 877-90o.

Kongregacija za bogoslužje in disciplino zakramentov. «Navodilo Liturgiam authenticam«. Acta Apostolicae sedis 93 (2001): 685-726.

—__. »Varietates legitimae«. Acta Apostolicae sedis 87 (1995): 295-297.

Kongregacija za bogoslužje. »Tretje navodilo za pravilno izvajanje Konstitucije o svetem bogoslužju«. V: Prenovljeno bogoslužje, 34-47. Ljubljana: Slovenski medškofijski liturgični svet, 1981. Prim. Acta Apostolicae sedis 62 (1970): 692-704. 
Lodi, Enzo. La liturgia della Chiesa: Guida allo studio della liturgia nelle sue fonti antiche e recenti. Studi e ricerche di liturgia 1. Bologna: EDB, 1999.

Missale Romanum ex decreto sacrosancti oecumenici concilii Vaticani II instauratum auctoritate Pauli PP. VI promulgatum Ioannis Pauli PP. II cura recognitum. Editio typica tertia. Vatikan: TPV, 2008.

Missale Romanum ex decreto ss. concilii Tridentini restitutum summorum pontificium cura recognitum. Editio typica 1962. MLP 1. Vatikan: LEV, 2007.

Missale secundum consuetudinem curiae romanae, Ms. Ottob. lat. 356, še neobjavljeni kodeks. Bibliotheca Apostolica Vaticana.

Mohlberg, Leo Cunibert, L. Eizenhöfer in P. Siffrin, ur. Liber sacramentorum Romanae Aecclesiae ordinis anni circuli (Cod. Vat. Reg. lat. 316/ Paris Bibl. Nat. 7193, 41/56). Sacramentarium Gelasianum (RED Fontes 4). Rim: Herder, 1981.

Movrin, David. »Hieronimov prevajalski credo«. Keria 2 (2000): 47-56.

Nakagaki, Frank. »Metodo integrale: Discorso sulla metodologia nell'interpretazione dei testi eucologici«. V: Fons vivus: Miscellanea liturgica in memoria di Don Eusebio Maria Vismara, ur. A. Cuva, 269-286. Zürich: Pas-Verlag: 1971.

Papež Frančišek. »Litterae apostolicae motu proprio datae: Magnum principium«. Acta Apostolicae sedis 109 (2017): 967-970.

Pecklers, Keith F. Dynamic Equivalence: The Living Language of Christian Worship. Collegeville, Minnesota: The Liturgical Press, 2003.

Richter, Gregor, in A. Schönfelder. Sacramentarium Fuldense saeculi x. Cod. Theol. 231 der K. Universitätsbibliothek zu Göttingen: Text und Bilderkreis (43 Tafeln); Als Festgabe des Historischen Vereins der Diözese Fulda zum 50 Jährigen Priesterjubiläum Sr. Eminenz des Hochwürdigsten Herrn Fürstbischofs von Breslau, Georg Kardinal Kopp, ehemaligen Bischofs von Fulda (1881-1887), Fulda 1912 (HBS 101). London: Saint Michael's Abbey Press, 1977.

Rimski misal - kakor ga je naročil prenoviti II. vatikanski cerkveni zbor in ga je razglasil papež Pavel VI., slovenska izdaja. Ljubljana: Slovenska liturgična komisija, 1992.

Sodi, Manlio. "La latinitas dei libri liturgici: L'eucologia del Tempus Adventus nel Missale Romanum di Paolo vi; dalla filologia alla teologia eucaristica«. V: Il latino e i cristiani: Un bilancio all'inizio del terzo millennio, ur. Enrico Covolo in Manlio Sodi (MSIL 17), 375-488. Vatikan: LEV, 2002.

Ward, Anthony, in C. Johnson, ur. Vetus Missale Romanum monasticum Lateranense, anno 1752 a Nicolao Antonellei editum (BELs Supplementa 4). Rim: CLV - Ed. Liturgiche, 1998.

Wilmart, André, E. A. Lowe in H. A. Wilson, ur. Missale de Bobio - Ms. Paris lat. 13246, Notes and Studies. HBS 61. London: Harrison and Sons, 1924.

Zimmermann, Joyce Ann. Liturgy as Language of Faith: A Liturgical Methodology in the Mode of Paul Ricoeur's Textual Hermeneutics. Lanham: University Press of America, 1988. 


\section{IZVLEČEK}

Prispevek predstavi sklop evholoških besedil na čast svetemu Hieronimu: od prvih omemb v Gelazijevem zakramentarju do prenovljenega rimskega misala Pavla vi. Orisan je potek kompozicije temeljnih zakramentarjev in misalov rimskega obreda, ki so vir, iz katerega se je bogato razširil obstoječ misal. Predstavljeni so vidiki, ki bi jih za zvest prenos misli, izraženih v latinski evhologiji, v drug jezik, lahko upoštevali. Razširjeni konteksti umeščenega besedila namreč v bogoslužju omogočajo liturgičnemu besedilu, da lahko postane učinkovit dogodek vere. Njihovo neupoštevanje pa učinkovitost besedila omejuje. Zaradi pretežno filološke metode prevedeno evhološko besedilo uporabnika lahko doseže šele s katehezo, homilijo ali komentarjem. Tak pristop je neprimerljivo hitrejši in zaradi še neizdelanih študij za vsak posamezni formular se ohranja vtis, da je zahtevni proces inkulturacije rimskega obreda nujno potrebno centralno nadzorovati. Predstavljena so tudi obvezujoča navodila, $s$ katerimi Cerkev že desetletja usmerja prevajanje in iz katerih postaja še bolj očitna teža in preroškost odločitev, ki jih je v korist vernikov naredila na drugem vatikanskem koncilu.

KLJUČNE BESEDE: evhologija, liturgija, prevod, zakramentar, misal, sveti Hieronim, rimski obred, mašni formular, konstitucija o svetem bogoslužju 
QUOD ORE SIMUL ET OPERA DOCUIT HIERONYMUS CONFESSOR, DOCTOR MAXIMUS: EUCHOLOGICAL TEXTS ABOUT SAINT JEROME AND THE VARIABILITY OF THEIR TRANSLATIONS

\section{ABSTRACT}

The article presents a set of euchological texts in honor of St. Jerome: from the first mentions in the Sacramentary of Gelasius to the renewed Roman Missal of Paul vi. It outlines how the fundamental sacramentaries and missals of the Roman Rite, which enrich the current missal, were composed. The article presents aspects that should be considered for faithfully transposing thoughts expressed in Latin euchology into other languages. Extended context facilitates the text's becoming an event of faith in liturgical acts. Inversely, not taking into account the extended context restricts the effectiveness of the text. Because the methods used are predominantly philological, a translated euchological text may reach its users only through catechesis, homily, or commentary. Such an approach is in fact disproportionately faster. Since extensive studies for all formularies of the present missal are still missing, the impression that the demanding process of the inculturation of the Roman Rite needs to be centrally controlled remains. The binding instructions with which the Church has guided processes of translations for decades are also presented. The development of these instructions shows the visionary nature of the Church's decisions on behalf of believers, which were made at the Second Vatican Council.

KEYWORDS: euchology, liturgy, translation, sacramentary, missal, St. Jerome, Roman Rite, mass formulary, Sacrosanctum Concilium, the Constitution on the Sacred Liturgy 